\title{
Impact of Compensation Factors on Teachers' Job Satisfaction: An Econometric Focus
}

\section{Dhanonjoy Kumar}

Associate Professor, Department of Management, Islamic University, Kushtia -7003, BANGLADESH

*Corresponding Contact:

Email: djoysk@yahoo.com

\begin{abstract}
Compensation satisfaction represents an important construct to organizations and to the field of Human Resource Management because it serves as a critical mediator between an organization's compensation policy and relevant behavioral and attitudinal outcomes (Blau, 1994; Lawler, 1981; Sturman \& Short, 2000). Compensation plays a significant role in determining employees' job satisfaction. According to Bozeman \& Gaughan (2011), the perception of being paid what one is worth predicts job satisfaction. This study, therefore, seeks to establish the effects of compensation on job satisfaction among primary school teachers, secondary school teachers and college teachers in Bangladesh. The questionnaires prepared for this purpose are applied to 250 teachers who are currently working in various schools and colleges in Bangladesh. The collected data have been analyzed through several techniques by using SPSS 17.0 program. Analyses of the study reveal that a significant relation is observed between the compensation factors and the job satisfaction of the teachers. Overall, the teachers' job satisfaction levels are not so elevated (mean value is 3.46 and a standard deviation is 0.982). Besides, the differences among the demographic variables (age, gender, monthly income level, job experience, and education) and the attitudes towards these factors and the levels of job satisfaction are also measured. This study provides significant information for educational institutions regarding compensation factors of job satisfaction.
\end{abstract}

Key Words: Job Satisfaction, Allowance, Basic Pay, Compensation, Retirement Benefits

\section{INTRODUCTION}

Human resource management becomes a significant aspect for an organization's prosperity. Because it is the human who builds up and develops the organization, to effectively and efficiently achieve its objectives. Today human assets are acknowledged as the most valuable asset for an organization so they should be properly administered (Kabene et al. 2006). However, it is not clear whether the compensation has the influence on teachers job satisfaction to cause the many stands offs. In an organization, employees are the key resources through which all the other objectives are achieved. Teachers are the employees of 
the educational organizations, and their job satisfaction promotes teaching and learning. Employees demonstrate pleasurable, positive attitudes when they are satisfied with their job (Millan, J. M.et al, 2011). Thus, high job satisfaction increases the productivity of an organization, in turn increasing the organizational performance. Compensation plays an important role in determining an employee's level of job satisfaction. According to Heathfield S.M. (2012), compensation is a fixed amount of money paid to an employee by an employer in exchange for a productive work performed. If individuals believe they are not compensated well, a state of emotional dissatisfaction develops. This emotional discrepancy grows and accumulates over time making employees to grumble as they render their service to the organization. Worse still, indicators such as absenteeism, turnover, go-slow, and strikes are experienced. Compensation has long been considered as one of the most important organizational rewards (Heneman \& Judge, 2000) because it allows employees to obtain other rewards (Lawler, 1971). Frederick Taylor (1911) was one of the earliest to recognize the motivating effects of pay when he proposed that workers put forth extra effort on the job to maximize their economic gains. Although this premise lost favor in the late 1920s with the emergence of the human relations school (Wren, 1994), money remains the fundamental way that organizations reward employees. Despite the longstanding importance of pay, it impacts on employees' job satisfaction remains to be explained.

\section{LITERATURE REVIEW}

Many researchers have conducted research works on different aspects regarding the impact of compensation factors on teachers' job satisfaction. Several important empirical research findings have been taken into consideration.

Muguongo, et. al. (2015) concluded that insurance coverage greatly affects job satisfaction among teachers. It was deduced that they are greatly satisfied with medical insurance. The bonuses only affect the job satisfaction of teachers slightly. The performance bonus makes teachers' care more about teaching well, pay incentives to motivate them and pay incentive schemes' objectives are achievable.

Bari, et. al. (2013) found that freedom, career development plan, valuation of employees, learning programs, open and comfortable work environment and good supervisory relations positively impact on employee attitude and performance in the workplace. They also suggested that focusing the factors that positively impacts the employee attitudes and performance would enhance the performance of employee and create a positive work environment which will also help grow the institute and its productivity.

Yaseen, A. (2013) found that pay, recognition, promotion opportunities, and meaningful work are important factors of compensation management which have a direct effect on job satisfaction on doctors. The main reason of doctor's dissatisfaction are not getting proper service structure and not finding their work meaningful. The government should increase the satisfaction of doctors by providing this type of nonfinancial compensation.

Mehta and Shaikh. (2012) conclude that compensation management system is good for all the organization operating in pharmaceutical industry. It offered more or similar components as their compensation structure, the competitive compensation structure that will help them to attract the talent pool from the labor market. Researchers identify that employee satisfaction towards compensation has a positive relationship with the employees' productivity level \& good compensation practices help them in terms of attracting the employee as well as regarding retaining the employees with the current organization. 
Malik,et.al. (2012) examined the impact of pay and promotion upon job satisfaction at the university level of Punjab. The findings reveal that pay has the significant impact on job satisfaction but the promotions have significant or partial impact on the job satisfaction of educationist. Other factors excepted pay and promotion can also be useful in the research. This research investigated the influence that pay and promotion has upon job satisfaction at the university level.

Liu. (2007) found increasing teacher compensation may help decrease teachers' attrition since many studies have identified low salaries as the main predictor of teacher erosion.

Liu and Meyer. (2005) found that there is a direct link between teachers' job satisfaction and teacher turnover. Their findings further demonstrated that teachers' perceptions show varying degrees of satisfaction with different aspects of their jobs that eventually have an effect on their decision to stay in teaching, leave teaching, or move to another school.

Liu and Meyer. (2005) found that teachers' dissatisfaction level with student behavior was almost as strong as their dissatisfaction with their income. However, they found little relationship between teachers' satisfaction with their income and their perception of student discipline problems.

Abel and Sewell. (1999) reported that inadequate administrative support and a lack of recognition for good teaching were principal causes of stress for urban teachers. Teachers in urban schools experience significantly more stress from poor working conditions and poor staff relations than teachers in rural schools.

Perie et al. (1997) examined characteristics of schools teachers', teachers' backgrounds, salaries, benefits, as well as working conditions, to identify their respective relationships to teachers' job satisfaction.

\section{OBJective OF THE Study}

By the gap found in the literature review, the main objective of the study is to assess the effect of compensation factors on teachers' job satisfaction. To achieve the main objective, the following sub-objectives are set:

- To establish the influence of basic pay on job satisfaction.

- To determine the effects of allowances on job satisfaction.

- To study the relationship between compensation factors and teachers' job satisfaction.

- To find out the important compensation factors for teachers' job satisfaction.

- To make some suggestions for policy implications.

\section{HYPOTHESES OF THE STUDY}

$\mathrm{H}_{\mathrm{o}}$ : There is a significant relation between the compensation factors and teachers' job satisfaction;

$H_{o}$ : There is a significant impact of the pay and allowances on teachers' job satisfaction;

\section{Methodology}

The study follows a quantitative approach to achieve the objectives of this study, which is descriptive in nature. There are five demographic variables such as age, gender, job experience, monthly income, and education, thirteen independent variables are taken for this study; job advancement, cooperation, creativity, job security, recognition, working environment, career development, salary/pay, bonus and other benefits, medical facilities, transportation facilities, retirement allowances and promotion facilities in work to identify 
their impact on teachers' satisfaction. The dependent variable is teachers' satisfaction. Simple random sampling was used to collect the data. Both primary and secondary data have been collected for the purpose of the study. A structured questionnaire in a five-point scale (1= Very Dissatisfied, 2 = Dissatisfied, 3 = Neither Satisfied nor Dissatisfied, $4=$ Satisfied, 5 = Very Satisfied) had been used in the survey. To achieve these objectives, 250 teachers were surveyed from four districts like Kushtia, Jhenaidah, Jessore, and Rajbari in Bangladesh. Data were collected from primary school, high school, and college teachers. The sample included primary school teachers' 80 high school teachers 80 and college teachers 90 . All types of data were processed through computer based Statistical Package for Social Science (SPSS) developed by Nie et al., (1975). Before feeding the data into a computer, all data were converted into numerical codes and the details of these coding were recorded in a code book. The Cronbach's alpha value $(\alpha)$ was found 0.8339 (from 13 independent and 01dependent variables), which was higher than the minimum acceptable level 0.70 suggested by Nunnally (1978). The descriptive statistics was based on frequency percentage, mean, standard deviation, correlation analysis, and regression analysis.

\section{THEORETICAL FRAMEWORK}

Compensation: Compensation refers to all the provided tangible and intangible rewards an employee receives from the employer as part of the employment relationship. The Society for Human Resource Management (SHRM, 2012) has defined compensation as a systematic approach to providing monetary value to employees in exchange for work performed. Compensation may achieve several purposes like assisting in recruitment, job performance, and job satisfaction. It can be said that compensation is the "glue" that binds the employee and the employer together in the organized sector, which is further codified in the form of a contract or a mutually binding legal document that spells out exactly how much should be paid to the employee and the components of the compensation package. Rewards and benefits are also types of compensation program that is important for employees (Cascio, 2003). Financially, the salaries must be fair according to employee's contribution. This gives a great sense of ownership and an interesting financial advantage for the employees. The non-financial reward should also be provided to employees for their contributions towards any organizations success (SHRM, 2012). Compensation can be defined as all of the rewards earned by employees in return for their labor. This includes:

- Direct financial compensation consisting of pay received in the form of wages, salaries, bonuses and commissions provided at regular and consistent intervals

- Indirect financial compensation including all financial rewards that are not included in direct compensation and can be understood to form part of the social contract between the employer and employee such as benefits, leaves, retirement plans, education, and employee services

- Non-financial compensation referring to topics such as career development and advancement opportunities, opportunities for recognition, as well as work environment and conditions

In determining effective rewards, however, the uniqueness of each employee must also be considered. People have different needs or reasons for working. The most appropriate compensation will meet these individual needs. To a large degree, adequate or fair compensation is in the mind of the employee. 
Job Satisfaction: People bring mental and physical abilities and time to their jobs. Many try to make a difference in their lives and in the lives of others through working. The reason for wanting a job is often considerably more than just a paycheck. Jobs can be looked at as the means used to achieve personal goals. When a job meets or exceeds an individual's expectation, the individual often experiences positive emotions. These positive emotions represent job satisfaction. Job satisfaction, in turn, is a major contributor to life satisfaction (Smith, 1998), a personal goal that many find worth pursuing.

\section{ANALYSIS AND INTERPRETATION OF DATA}

Table 1: Profile of Respondents in Terms of Age, Gender, Job experience, Monthly Income and Education

\begin{tabular}{|c|c|c|c|c|c|}
\hline \multicolumn{6}{|c|}{ Age } \\
\hline & 25 years 30 & 31 years 35 & 36 years 40 & 41 years 45 & 46 years to above \\
\hline Frequency & 34 & 44 & 67 & 42 & 63 \\
\hline Percentage & 13.6 & 17.6 & 28.8 & 16.8 & 25.2 \\
\hline \multicolumn{6}{|c|}{ Gender } \\
\hline & \multicolumn{3}{|c|}{ Male } & \multicolumn{2}{|c|}{ Female } \\
\hline Frequency & \multicolumn{3}{|c|}{185} & \multicolumn{2}{|c|}{65} \\
\hline Percentage & \multicolumn{3}{|c|}{74} & \multicolumn{2}{|r|}{26} \\
\hline \multicolumn{6}{|c|}{ Job Experience } \\
\hline & 1 year 5 & 6 years 10 & 11 years 15 & 16 years 20 & 21 years to above \\
\hline Frequency & 67 & 32 & 62 & 38 & 51 \\
\hline Percentage & 26.8 & 12.8 & 24.8 & 15.2 & 20.4 \\
\hline \multicolumn{6}{|c|}{ Monthly Income } \\
\hline & \multicolumn{2}{|c|}{1 taka 10,000} & \multicolumn{2}{|c|}{10,001 taka 20,000} & 20,001 taka 30,000 \\
\hline Frequency & \multicolumn{2}{|c|}{63} & \multicolumn{2}{|c|}{154} & 33 \\
\hline Percentage & \multicolumn{2}{|c|}{25.2} & \multicolumn{2}{|c|}{61.6} & 13.2 \\
\hline \multicolumn{6}{|c|}{ Education } \\
\hline & \multicolumn{2}{|c|}{ SSC to HSC } & \multicolumn{2}{|c|}{ Bachelor } & Masters and above \\
\hline Frequency & \multirow{2}{*}{\multicolumn{2}{|c|}{$\frac{10}{4}$}} & \multicolumn{2}{|c|}{64} & 176 \\
\hline Percentage & & & \multicolumn{2}{|c|}{25.6} & 70.4 \\
\hline
\end{tabular}

Source: Field Survey

Calculation through SPSS 17.0

Table 2: Descriptive Statistics of 13 Independent Variables and 01 Dependent Variable

\begin{tabular}{|l|c|c|}
\hline Variables & Mean & Std. Deviation \\
\hline Cooperation & 3.92 & .859 \\
\hline Creativity & 3.81 & .945 \\
\hline Recognition & 3.72 & .948 \\
\hline Job Advancement & 3.68 & .893 \\
\hline Working Environment & 3.61 & .968 \\
\hline Job Security & 3.54 & 1.072 \\
\hline Teachers Job Satisfaction & 3.46 & .982 \\
\hline Career Development & 3.32 & 1.061 \\
\hline Salary/Pay & 3.06 & 1.114 \\
\hline Promotion & 2.89 & 1.253 \\
\hline Retirement Allowances & 2.53 & 1.223 \\
\hline Bonus and others & 2.52 & 1.179 \\
\hline Medical Service & 2.30 & 1.112 \\
\hline Transportation Service & 2.26 & 1.110 \\
\hline
\end{tabular}

Source: Field Survey

Calculation through SPSS 17.0 
Table 2 represents the descriptive statistics. From all variables the highest mean value is 3.92 (cooperation among the teachers) and the lowest mean value is 2.26 (transportation facilities).

Table 3: Correlation Analysis of Teachers' Job Satisfaction with Compensation Factors

\begin{tabular}{|l|c|c|c|c|c|c|c|c|c|c|c|c|c|c|}
\hline Name of variables & 1 & 2 & 3 & 4 & 5 & 6 & 7 & 8 & 9 & 10 & 11 & 12 & 13 & 14 \\
\hline 1.Teachers Satisfaction & 1 & .242 & .184 & .292 & .410 & .360 & .432 & .364 & .377 & .394 & .262 & .291 & .399 & .554 \\
\hline 2.Job Advancement & & 1 & .465 & .299 & .070 & .368 & .188 & .123 & .079 & .054 & -.036 & -.051 & .041 & .046 \\
\hline 3.Cooperation & & & 1 & .378 & .206 & .369 & .274 & .278 & .097 & -.036 & -.065 & -.131 & .115 & .104 \\
\hline 4.Creativity & & & & 1 & .259 & .332 & .372 & .353 & .090 & .110 & .003 & -.048 & .181 & .094 \\
\hline 5. Job Security & & & & & 1 & .285 & .358 & .253 & .159 & .060 & .054 & -.049 & .276 & .287 \\
\hline 6. Recognition & & & & & & 1 & .535 & .351 & .239 & .082 & -.059 & -.011 & .162 & .278 \\
\hline 7. Working Environment & & & & & & & 1 & .465 & .337 & .184 & .163 & .197 & .240 & .322 \\
\hline 8. Career Development & & & & & & & & 1 & .491 & .258 & .161 & .221 & .240 & .296 \\
\hline 9. Salary/pay & & & & & & & & & 1 & .522 & .366 & .332 & .293 & .401 \\
\hline 10. Bonus and others & & & & & & & & & & 1 & .706 & .6281 & .501 & .483 \\
\hline 11. Medical Facilities & & & & & & & & & & & & .727 & .533 & .433 \\
\hline 12. Transportation Facilities & & & & & & & & & & & & 1 & .426 & .414 \\
\hline 13. Retirement Allowances & & & & & & & & & & & & & 1 & .435 \\
\hline 14. Promotion Facilities & & & & & & & & & & & & & & 1 \\
\hline
\end{tabular}

Source: Field Survey

Calculation through SPSS 17.0

Table 3 shows that all compensation factors are positively related with teacher's job satisfaction. Among all the independent variables highest positive correlation existing between teachers' satisfaction and promotion facilities (0.554) and lowest positive correlation exist between teachers' satisfaction and cooperation (0.184).

Table 4(a) and 4 (b) Linear Regression Analyses of Teachers' job satisfaction with compensation factors

Table 4 (a): Model Summary

\begin{tabular}{|c|c|c|c|c|}
\hline Model & $\mathrm{R}$ & R Square & Adjusted R Square & Std. Error of the Estimate \\
\hline 1 & $.703(\mathrm{a})$ & .495 & .467 & .717 \\
\hline
\end{tabular}

Source: Field Survey

Calculation through SPSS 17.0

Tables 4(a) and 4(b) represent the regression analysis. The analysis shows that the R-Square value is 0.495 . It indicates that a good proportion of variation $(50 \%)$ exists between the dependent variable (teachers' job satisfaction) is explained by the total variation of the 13 independent variables. From all the independent variables significant values of only four variables, like - job advancement, job security, medical service facilities and promotion facilities are less than the $\mathrm{P}$ value 0.05 . Another three independent variables like working environment, bonus and other allowances and retirement allowances significant values are less than the $\mathrm{P}$ value 0.10. It indicates that the teachers think job advancement, job security, medical service facilities, promotion facilities, working environment, bonus and other allowances and retirement allowances as the important compensation factors for their profession. 
Table 4 (b): Coefficients

\begin{tabular}{|c|c|c|c|c|c|c|}
\hline & \multirow[t]{2}{*}{ Model } & \multicolumn{2}{|c|}{$\begin{array}{l}\text { Un standardized } \\
\text { Coefficients }\end{array}$} & \multirow{2}{*}{$\begin{array}{c}\begin{array}{c}\text { Standardized } \\
\text { Coefficients }\end{array} \\
\text { Beta }\end{array}$} & \multirow[b]{2}{*}{$\mathbf{t}$} & \multirow[b]{2}{*}{ Sig. } \\
\hline & & B & Std. Error & & & \\
\hline \multirow[t]{14}{*}{1} & (Constant) & .154 & .308 & & .501 & .617 \\
\hline & Job Advancement & .181 & .061 & .164 & 2.985 & .003 \\
\hline & Co-operation & -.066 & .066 & -.058 & -1.003 & .317 \\
\hline & Creativity & .090 & .058 & .087 & 1.543 & .124 \\
\hline & Job Security & .192 & .049 & .209 & 3.884 & .000 \\
\hline & Recognition & .019 & .064 & .019 & .303 & .763 \\
\hline & Working Environment & .117 & .063 & .115 & 1.844 & .066 \\
\hline & Career Development & .031 & .056 & .033 & .546 & .585 \\
\hline & Salary/Pay & .053 & .055 & .060 & .972 & .332 \\
\hline & Bonus and others & .115 & .064 & .139 & 1.806 & .072 \\
\hline & Medical Service & -.146 & .072 & -.166 & -2.047 & .042 \\
\hline & Transportation Service & .101 & .065 & .114 & 1.545 & .124 \\
\hline & Retirement Allowances & .080 & .048 & .100 & 1.659 & .098 \\
\hline & Promotion & .253 & .047 & .322 & 5.415 & .000 \\
\hline
\end{tabular}

Source: Field Survey

Calculation through SPSS 17.0

\section{FINDINGS OF THE STUDY}

- Compensation factors significantly affect the job satisfaction of the teachers.

- Compensation factors have a positive relationship with teachers' job satisfaction. (Table 3)

- Teachers are unhappy about their salary/pay, promotion, retirement allowances, bonus and other benefits, medical facilities and transportation facilities. Teachers are not completely happy with compensation policy. (Table 2)

- Job advancement, job security, medical service facilities, promotion facilities, working environment, bonus and other allowances and retirement allowances are the important factors for teachers' job satisfaction. (Table 4)

\section{Conclusions ANd RECOMmEndations}

Compensation is one of the drives that motivate workers. From this study, it can be argued that if teachers are compensated well, they will be encouraged, assured and will have positive feelings towards their job and this would result to job satisfaction. This is also shared by (Bennel, 2007). The findings imply that poor compensation is a major cause of teachers' job dissatisfaction. From the findings, the study concludes that the compensation, the teachers receive does not match with their job description. The study also concludes that the allowances such as medical allowance, transportation allowance, and retirement allowance that the teachers receive affect their job satisfaction. The study further concludes that promotion coverage greatly affects job satisfaction of the teachers. The study finally 
concludes that the nonfinancial compensation that affects the teachers' satisfaction includes job advancement, job security and working environment. Therefore, the government should address teachers' compensation issues to enhance teacher's job satisfaction. Based on the findings of the study, it can be concluded that teachers in Bangladesh are not well compensated and as a result they are not so satisfied. This research can be good guidelines for human resource management practices in the education sector in Bangladesh.

\section{REFERENCES}

Abel, M. H., \& Sewell, J. (1999). Stress and Burnout in Rural and Urban Secondary School Teachers. Journal of Educational Research, 92(5), 287-295.

Ahmed, M. (2015). The Role of Self-esteem and Optimism in Job Satisfaction among Teachers of Private Universities in Bangladesh. Asian Business Review, 1(2), 114-120. doi: http://dx.doi.org/10.18034/abr.v1i2.322

Bari, N., Arif, U., \& Shoaib, A. (2013). Impact of Non-Financial Rewards on Employee Attitude and Performance in the Workplace. A Case Study of Business Institute of Karachi, International Journal of Scientific and Engineering Research, Pakistan, 4(7), 2554-2559.

Blau, G. (1994). Testing the effect of level and importance of pay referents on pay level satisfaction. Human Relations, 47, 1251-1268.

Bozeman, B. \& Gaughan, M., (2011). Job Satisfaction among University Faculty: Individual, Work, and Institutional Determinants. Journal of Higher Education, 82(2), 154-186

Cascio, W. F. (2003). Managing human resources: Productivity, Quality of work, life, Profits. 6th ed. New-York: McGraw-Hill Higher Education

Heathfield, S. M. (2012). Salary. Retrieved on 1 September 2012 from http://humanresources.about.com/od/glossarys/g/salary.htm

Heneman, H. G. \&, Judge, T.A. (2000), Compensation Attitudes, Compensation in Organizations, JosseyBass, San Francisco, CA, pp. 61-71.

Islam, S. (2016). A New Method to Measure the Job Satisfaction Level of an Employee. Engineering International, 4(1), 19-24. doi:http://dx.doi.org/10.18034/ei.v4i1.826

Kabene, S. M. Orchard, C., Howard, J.M., Soriano, M. A., Leduc, R. (27 July 2006). The importance of human resources management in health care: a global context.

Kumar, D. (2016). Job Satisfaction of Commercial Bank Employees in Bangladesh: An Empirical Study. ABC Journal of Advanced Research, 5(2), 61-70. Retrieved from http://iproclaim.my/archive/index.php/abcjar/article/view/214

Kumar, D., Hossain, A., \& Gope, M. (2015). Role of Micro Credit Program in Empowering Rural Women in Bangladesh: A Study on Grameen Bank Bangladesh Limited. Asian Business Review, 3(4), 114-120.

Kumar, D., Hossain, M., \& Jebin, A. (2016). Organizational Commitment among the Employees of NGOs in Bangladesh: An Empirical Study. American Journal of Trade and Policy, 3(2), 55-60.

Lawler, E. E (2000). Strategic Pay, Jossey-Bass, San Francisco, CA.

Lawler, E. E. III (1981). Pay and organizational development. Reading, MA: Addison- Wesley.

Liu, X. S. (2007). The Effect of Teacher Influence at School on First-Year Teacher Attrition: A Multilevel Analysis of the Schools and Staffing Survey for 1999-2000. Educational Research and Evaluation, 13(1), 1 .

Liu, X. S., \& Meyer, J. P. (2005). Teachers' Perceptions of Their Jobs: A Multilevel Analysis of the Teacher Follow-Up Survey for 1994-95. Teachers College Record, 107(5), 985.

Locke, E.A. (1976). The nature and causes of job satisfaction. Handbook of industrial and organizational psychology. 
Malik, M. E., Danish, R, Q. \& Munir, Y. (2012). The Impact of Pay and Promotion on Job Satisfaction: Evidence from Higher Education Institutes of Pakistan, American Journal of Economics, Special Issue, 6-9.

Mehta, M. D. \& Shaikh,. M, N. (2012). Study on Compensation Management System \& its Impacts on Employees and Organization Magnitudes in Pharmaceutical Industry at Ankles war Belt, Global Research Analysis, 1 (7), 76-77.

Milkovich, G. T., \& Newman, J. M. (2002). Compensation, New York: McGraw Hill.

Milkovich, G.T., \& J.M. Newman. (1999).Compensation, New York: Irwin McGraw-Hill.

Millan, et.al. (2011), Determinants of Job Satisfaction across the EU-15: A Comparison of Self-Employed and Paid Employees, Tinbergen Institute Discussion Paper.

Muguongo, et. al. (2015) Effects of Compensation on Job Satisfaction Among Secondary School Teachers in Maara Sub - County of Tharaka Nithi County, Kenya, Journal of Human Resource Management, 3(6),47-59.

Nasima, M., \& Alam, N. (2015). Job Satisfaction among Female Fculties of Different Public and Private Universities in Bangladesh: A Comparative Analysis. ABC Journal of Advanced Research, 4(1), 16 - 26.

Norman, H. Nie. (1975). Statistical Package for the Social Sciences. New York: McGraw-Hill International.

Smith, P. L., Smits, S. J., \& Hoy, F. (1998). Employee work attitudes: The subtle influence of gender. Human Relations, 51(5), 649-666.

Society for Human Resource Management (2012). Employee Job Satisfaction and Engagement. A research report by SHRM. Retrieved from www.shrmstore. shrm.org.

Sturman, M. C., \& Short, J. C. (2000). Lump-sum bonus satisfaction: Testing the construct validity of a new pay satisfaction dimension. Personnel Psychology, 53, 673-700.

Taylor, F. W. (1911). The Principles of Scientific Management, New York, NY, USA, and London, UK: Harper \& Brothers.

Wren, D. A. (1994). The evolution of management thought. (4th ed.) New York: Wiley.

Yaseen, A. (2013). Effect of Compensation Factors on Employee Satisfaction - A Study of Doctor's Dissatisfaction in Punjab, International Journal of Human Resource Studies. 3(1), (142-157) 
Publish Online and Print Version Both

ISSN Online: 2307-9592 